\title{
Controlled-atmosphere Suppression of ACC Synthase and ACC Oxidase in 'Golden Delicious' Apples during Long-term Cold Storage
}

\author{
James R. Gorny and Adel A. Kader ${ }^{1}$ \\ Department of Pomology, University of California, Davis, CA 95616
}

\begin{abstract}
Additional index words. reduced $\mathrm{O}_{2}$, elevated $\mathrm{CO}_{2}$, ethylene biosynthesis, $\mathrm{CA}$
Abstract. Preclimacteric 'Golden Delicious' apples (Malus domestica Borkh.) were stored at $0{ }^{\circ} \mathrm{C}$ in: air; air $+5 \% \mathrm{CO}_{2}$;

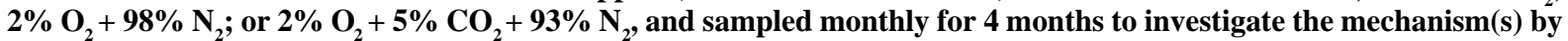
which reduced $\mathrm{O}_{2}$ and/or elevated $\mathrm{CO}_{2}$ atmospheres inhibit $\mathrm{C}_{2} \mathrm{H}_{4}$ biosynthesis. Ethylene biosynthesis rates and in vitro ACS activity were closely correlated in all treatments, while in vitro ACO activity significantly increased over time regardless of the treatment. Only a small amount of $\mathrm{C}_{2} \mathrm{H}_{4}$ biosynthesis inhibition by lowered $\mathrm{O}_{2}$ and/or elevated $\mathrm{CO}_{2}$ atmospheres could be accounted for by suppressed induction of ACO activity. Western blot analysis demonstrated that apples held for 2 months in lowered $\mathrm{O}_{2}$ and/or elevated $\mathrm{CO}_{2}$ atmospheres had significantly reduced abundance of $\mathrm{ACO}$ protein, compared to fruit held in air. Northern blot analysis of ACS and ACO transcript abundance revealed that reduced $\mathrm{O}_{2}$ and/or elevated $\mathrm{CO}_{2}$ atmospheres delay induction and reduce the abundance of both transcripts. Reduced $\mathrm{O}_{2}$ and/or elevated $\mathrm{CO}_{2}$ atmospheres reduce $\mathrm{C}_{2} \mathrm{H}_{4}$ biosynthesis by delaying and suppressing expression of ACS at the transcriptional level and by reducing the abundance of active $\mathrm{ACO}$ protein. Chemical names used: 1-aminocyclopropane-1-carboxylic acid (ACC), ACC synthase (ACS), ACC oxidase (ACO), ethylene $\left(\mathrm{C}_{2} \mathrm{H}_{4}\right), S$-adenosylmethionine (AdoMet).
\end{abstract}

Atmospheres reduced in $\mathrm{O}_{2}$ and enriched in $\mathrm{CO}_{2}$ have been used commercially in the United States since the 1930s to significantly extend the storage life of apples (Abeles et al., 1992). It is generally accepted that 1$) \mathrm{C}_{2} \mathrm{H}_{4}$ is the key regulator of apple ripening, and 2) the suppression of $\mathrm{C}_{2} \mathrm{H}_{4}$ biosynthesis and action is one of the primary mechanisms by which controlled atmospheres extend the storage life of apples. Burg and Thimann (1959) demonstrated that a $3 \% \mathrm{O}_{2}$ atmosphere inhibited $\mathrm{C}_{2} \mathrm{H}_{4}$ production of apples by $50 \%$ and this cannot be attributed solely to low $\mathrm{O}_{2}$ effects on respiration (Banks et al., 1984). Kinetic experiments of Burg and Burg (1967) indicated that $\mathrm{CO}_{2}$ is a competitive inhibitor of $\mathrm{C}_{2} \mathrm{H}_{4}$ action, and elevated levels of $\mathrm{CO}_{2}$ also reduce $\mathrm{C}_{2} \mathrm{H}_{4}$ biosynthesis.

Ethylene biosynthesis in climacteric fruit tissue is a feed forward biochemical mechanism referred to as autocatalysis (Peacock, 1972). A model to explain the induction of ethylene autocatalysis was put forth by McMurchie et al. (1972). This model describes two $\mathrm{C}_{2} \mathrm{H}_{4}$ biosynthesis induction mechanisms designated System I and System II. Immature fruit have a nonautocatalytic System $\mathrm{I} \mathrm{C}_{2} \mathrm{H}_{4}$ biosynthetic capability and when the competency to ripen occurs, an autocatalytic System $\mathrm{II} \mathrm{C}_{2} \mathrm{H}_{4}$ biosynthetic capability is induced. Once the competency to ripen occurs, System $\mathrm{IC}_{2} \mathrm{H}_{4}$ is thought to bind to a receptor, and this causes the upregulation of genes involved in $\mathrm{C}_{2} \mathrm{H}_{4}$ biosynthesis. Burg and Burg (1967) postulated that $\mathrm{CO}_{2}$ displaces $\mathrm{C}_{2} \mathrm{H}_{4}$ at this receptor binding site and that low $\mathrm{O}_{2}$ concentrations impede the binding of $\mathrm{C}_{2} \mathrm{H}_{4}$ to the receptor, hence blocking the feed forward upregulation of $\mathrm{C}_{2} \mathrm{H}_{4}$ biosynthesis.

Oxygen and $\mathrm{CO}_{2}$ concentrations can also affect the activity of the enzymes involved in $\mathrm{C}_{2} \mathrm{H}_{4}$ biosynthesis, particularly $\mathrm{ACO}$, which requires $\mathrm{CO}_{2}$ and $\mathrm{O}_{2}$ for activity (Poneleit and Dilley, 1993; Yip et al., 1988). Therefore, the mode of action by which lowered $\mathrm{O}_{2}$ and elevated $\mathrm{CO}_{2}$ tensions reduce $\mathrm{C}_{2} \mathrm{H}_{4}$ biosynthesis may be

Received for publication 20 Nov. 1995. Accepted for publication 26 Mar. 1996 Research supported by the U.S. Dept. of Agriculture research agreement no. 58319R-3-004. The cost of publishing this paper was defrayed in part by the payment of page charges. Under postal regulations, this paper therefore must be hereby marked advertisement solely to indicate this fact.

${ }^{1}$ To whom reprint requests should be addressed. direct (i.e., reduction in enzyme specific activity) and indirect (i.e., blocking System II upregulation of $\mathrm{C}_{2} \mathrm{H}_{4}$ biosynthesis).

The $\mathrm{C}_{2} \mathrm{H}_{4}$ biosynthetic pathway was elucidated in 1979 by Adams and Yang, who determined $\mathrm{C}_{2} \mathrm{H}_{4}$ was derived from AdoMet, and that $\mathrm{ACC}$ was the immediate precursor to $\mathrm{C}_{2} \mathrm{H}_{4}$. Recently, the enzymes involved in $\mathrm{C}_{2} \mathrm{H}_{4}$ biosynthesis (i.e., $\mathrm{ACS}$ and $\mathrm{ACO}$ ) have been isolated, purified, and studied extensively. Molecular cloning techniques have also allowed for the isolation of the genes that code for each of these enzymes (Dong et al., 1991; Dong et al., 1992).

Although Burg and Burg (1967) hypothesized about the mode of action by which reduced $\mathrm{O}_{2}$ and elevated $\mathrm{CO}_{2}$ atmospheres impede $\mathrm{C}_{2} \mathrm{H}_{4}$ biosynthesis, no one has tested the hypothesis, nor has it been demonstrated that reduced $\mathrm{O}_{2}$ and/or elevated $\mathrm{CO}_{2}$ concentrations effect the transcript abundance of ACS and/or ACO. The objective of this study was to determine how reduced $\mathrm{O}_{2}$ and/or elevated $\mathrm{CO}_{2}$ concentrations inhibit $\mathrm{C}_{2} \mathrm{H}_{4}$ biosynthesis. Specifically, we investigated the effects of these treatments on ACS and ACO transcript abundance, protein abundance, and in vitro enzyme activity.

\section{Materials and Methods}

Plant materials and storage conditions. 'Golden Delicious' apples harvested from a commercial orchard near Sebastapol, Calif. (Sonoma County), were transported to our laboratory in Davis, Calif. Ethylene production, internal $\mathrm{C}_{2} \mathrm{H}_{4}$ concentration, flesh firmness, titratable acidity, soluble solids content, and skin color were evaluated on the day of harvest to assess the maturity of the apples. After cooling overnight in cold storage, apples (three fruit/1-L jar) were placed at $0{ }^{\circ} \mathrm{C}$ in a continuous $\left(100 \mathrm{~mL} \cdot \mathrm{min}^{-1}\right)$ flow of humidified air, air $+5 \% \mathrm{CO}_{2}\left(19.9 \% \mathrm{O}_{2}+5 \% \mathrm{CO}_{2}+75.1 \%\right.$ $\left.\mathrm{N}_{2}\right), 2 \% \mathrm{O}_{2}+98 \% \mathrm{~N}_{2}$, or $2 \% \mathrm{O}_{2}+5 \% \mathrm{CO}_{2}+93 \% \mathrm{~N}_{2}$. Each jar of three individual fruit was considered a replicate and all data points are represented by the means and standard error of three replicates. At the start of the experiment, and after 1,2,3, and 4 months at 0 ${ }^{\circ} \mathrm{C}$, ripening parameters, such as soluble solids, titratable acidity, and skin color, were evaluated immediately upon removal from storage. Ethylene production rates of each replicate of apples were 
determined monthly using a Carle gas chromatograph equipped with a flame ionization detector. Tissue samples used in Northern and Western blot analysis were frozen in liquid $\mathrm{N}_{2}$ and stored at $80{ }^{\circ} \mathrm{C}$ until analysis.

In vitro ACS enzyme activity. Upon removal from storage treatments, apple cortical and skin tissue were homogenized in a chilled Waring blender with $1 \mathrm{~mL} \cdot \mathrm{g}^{-1}$ of $4{ }^{\circ} \mathrm{C}$ extraction media [400 mм potassium phosphate $(\mathrm{pH} 8.5), 1$ mм EDTA, $0.5 \% 2-$ mercaptoethanol, $0.01 \mathrm{~mm}$ pyridoxal phosphate]. The homogenate was filtered through four layers of cheese cloth, and then centrifuged at 28,000× $g$ for $30 \mathrm{~min}$. The supernatant was discarded and the pellet was resuspended in extraction media. The resuspended pellet was then centrifuged at $28,000 \times g$ for $20 \mathrm{~min}$ and the supernatant was discarded. The resulting pellet was solubilized and ACS activity was assayed as described by Yip et al. (1991).

In vitro ACO enzyme. Upon removal from storage treatments, apple cortical and skin tissue were frozen in liquid nitrogen and homogenized by mortar and pestle in $2 \mathrm{~mL} \cdot \mathrm{g}^{-1}$ tissue of extraction medium containing $400 \mathrm{~mm} 3$-[N-Morpholino] propanesulfonic acid (Mops) buffer (pH 7.2), 10\% glycerol, $30 \mathrm{~mm}$ ascorbate and 5\% (w/w) PVPP (Dong et al., 1992; Fernandez-Maculet and Yang, 1992). After the slurry melted, it was filtered through four layers of cheese cloth and centrifuged at $28,000 \times g$ for $20 \mathrm{~min}$. The supernatant (enzyme preparation) was used for enzyme assays. The standard reaction mixture contained $50 \mathrm{~mm}$ Mops ( $\mathrm{pH} 7.2)$, $10 \%$ glycerol, $1 \mathrm{~mm}$ ACC, $0.02 \mathrm{~mm} \mathrm{FeSO}_{4}, 5 \mathrm{~mm}$ ascorbate, $1 \mathrm{~mm}$ dithiothreitol (Poneleit and Dilley, 1993), and $20 \mathrm{~mm}$ sodium bicarbonate (Smith and John, 1993). The enzyme assay reaction was initiated by the addition of $0.2 \mathrm{~mL}$ of enzyme preparation to 15-mL test tube, which contained the standard reaction mixture $(1.8 \mathrm{~mL})$. The test tube was then sealed and, after $1 \mathrm{~h}$ incubation, with shaking at $30{ }^{\circ} \mathrm{C}$, a $1-\mathrm{mL}$ gas sample was withdrawn with a syringe from the headspace for $\mathrm{C}_{2} \mathrm{H}_{4}$ determination.

Protein assay. Protein content of enzyme assay extracts and protein extracts for Western blot analysis were determined by the method of Bradford (1976) using a Bio-Rad protein assay kit, and BSA as a standard.

ACO Western blots. The amount of ACO protein present during treatments was determined via Western blot analysis. Total proteins were extracted from apple cortical and skin tissue by the method of Paull and Chen (1990), with the following modifications. Ten grams of apple tissue was extracted in a media containing $500 \mathrm{~mm}$ Tris $\mathrm{pH}$ (7.4), $500 \mathrm{~mm}$ sucrose, $100 \mathrm{~mm} \mathrm{KCl,} 50 \mathrm{~mm}$ EDTA, $0.2 \%$ 2-mercaptoethanol, $0.2 \%$ Triton $\mathrm{X}-100$, and 5\% PVPP.

Gel electrophoresis and immunoblotting. Thirty micrograms of total proteins per lane were separated by SDS-PAGE as described by Laemmli (1970). Polyacrylamide gels (15\%) were stained with either Coomassie blue, or were electroblotted onto supported nitrocellulose membranes (Bio-Rad). The membranes were probed with a rabbit polyclonal antibody specific to ACO (Dong et al, 1992), a gift from the laboratory of S.F. Yang. Immunodetection with the alkaline phosphatase reaction was carried out as described by Birkett et al., 1985. Duplicate SDS-PAGE gels were run simultaneously, with one gel being stained with Coomassie blue to determine if equal loading of lanes had occurred, and the other was used for electroblotting and subsequent Western blot analysis.

RNA isolation, electrophoresis, and transfer to nylon membranes. Total RNA was isolated from apples as described by Manning (1991), and quantified spectrophotometrically. Total RNA $(25 \mu \mathrm{g} /$ lane) was separated by electrophoresis in a $1.2 \%$ agarose gel containing $2.2 \mathrm{M}$ formaldehyde in Mops running buffer (Sambrook et al., 1989) and blotted to a nylon membranes
(Amersham). The RNA was cross-linked to the nylon membranes by exposure to UV radiation $\left(120 \mathrm{~mJ} \cdot \mathrm{cm}^{-2}\right)$, using a Fischer Brand UV Crosslinker (model FB-UVXL-100). The blots were then stained and destained by the method of Herrin and Schmidt (1988) to visualize the $18 \mathrm{~S}$ and $28 \mathrm{~S}$ ribosomal bands and determine if equal lane loading and transfer had occurred before blot probing was initiated.

Probe preparation and Northern blotting. Plasmid DNA was digested with the appropriate endonucleases and separated by agarose gel electrophoresis. DNA bands containing the inserts pAAS2 for ACS (Dong et al., 1991) and pAE12 for ACO (Dong et al., 1992) were collected and purified using a GeneClean kit (Bio 101, LaJolla, Calif.). Both cDNA inserts used as probes were originally derived from 'Golden Delicious' apples and were gifts from the laboratory of S.F. Yang. The cDNA was labeled with [32P]dCTP, using a Boehringer Mannheim random primer labeling kit (Boehringer Mannheim Biochemica, GmbH), and hybridized to the membranes using routine procedures. Autoradiography was carried out at $-80^{\circ} \mathrm{C}$ using Kodak XAR-5 film and intensifying screens (Cronex, Du Pont, Newtown, Conn.).

\section{Results and Discussion}

Controlled atmosphere treatment effects on ripening. At harvest the apples used had a soluble solids content of $14.5 \% \pm 0.7 \%$, titratable acidity of $0.47 \% \pm 0.05 \%$, flesh firmness of $82.3 \pm 4.5 \mathrm{~N}$, $\mathrm{L}^{*} \mathrm{a} * \mathrm{~b}$ color ' $\mathrm{a}$ ' value of $-18.3 \pm 0.8$, and an internal $\mathrm{C}_{2} \mathrm{H}_{4}$ content of $0.04 \pm 0.01 \mu \mathrm{L} \cdot \mathrm{L}^{-1}$. These apples were at commercial maturity and preclimacteric with regard to $\mathrm{C}_{2} \mathrm{H}_{4}$ biosynthesis. During cold storage for 4 months, all treatments showed an increase in soluble solids content with no significant differences or trends among treatments (data not shown). Fruit titratable acidity decreased over time regardless of the treatment applied (data not shown). However, the $2 \% \mathrm{O}_{2}+5 \% \mathrm{CO}_{2}$ treatment slowed this decline significantly compared to the air treatment, and the air $+5 \% \mathrm{CO}_{2}$ and $2 \%$ $\mathrm{O}_{2}$ treatments were intermediate in their loss of titratable acidity over time. The retention of organic acids in apples held in low $\mathrm{O}_{2}$ and/or elevated $\mathrm{CO}_{2}$ atmospheres has been well documented

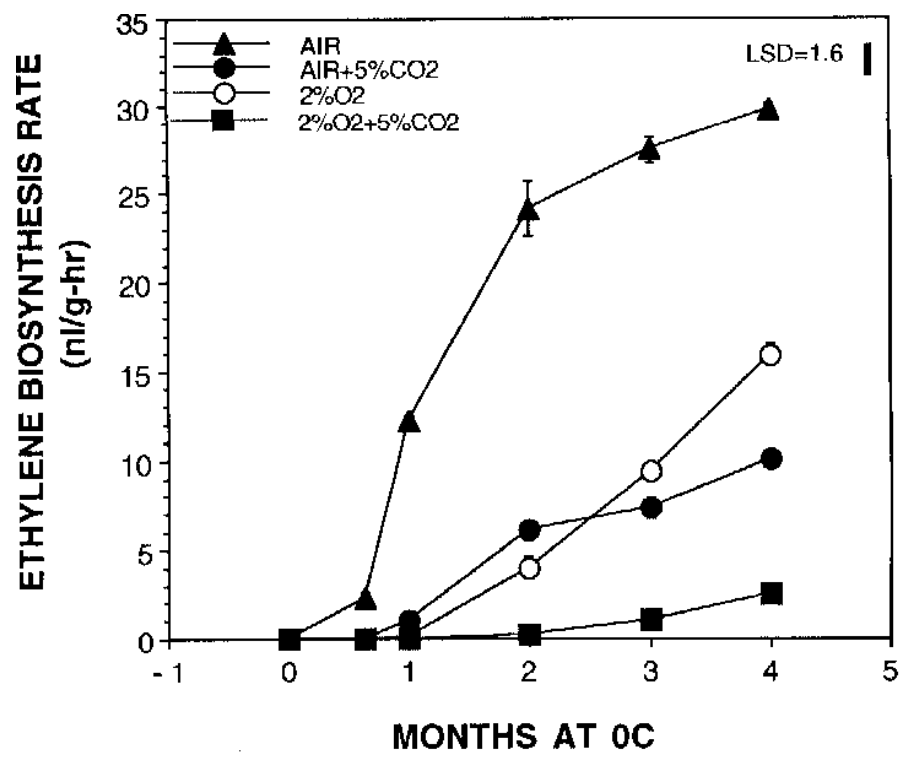

Fig. 1. Ethylene biosynthesis rates of 'Golden Delicious' apples held in atmospheres of air, air $+5 \% \mathrm{CO}_{2}, 2 \% \mathrm{O}_{2}$, or $2 \% \mathrm{O}_{2}+5 \% \mathrm{CO}_{2}$ at $0{ }^{\circ} \mathrm{C}$. Data are the means ( \pm SE) of three replicates. Pooled LSD at the $5 \%$ level is shown. 


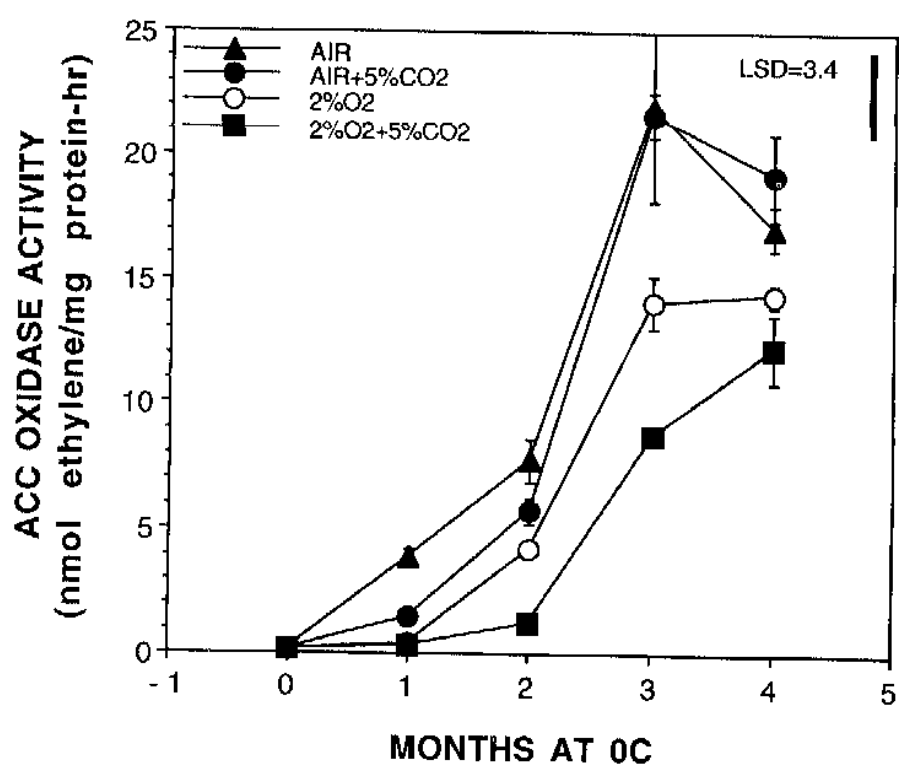

Fig. 2. In vitro AES activity of 'Golden Delicious' apples held in atmospheres of air, air $+5 \% \mathrm{CO}_{2}, 2 \% \mathrm{O}_{2}$, or $2 \% \mathrm{O}_{2}+5 \% \mathrm{CO}_{2}$ at $0{ }^{\circ} \mathrm{C}$. Data are the means $( \pm \mathrm{SE})$ of three replicates. Pooled LSD at the $5 \%$ level is shown.

(Kollas, 1964). There was no significant differences in Minolta L*a*b color ' $a$ ' values among treatments until month 4 when the air treatment was significantly different (i.e., less green) than the other treatments (data not shown). The air treated fruit exhibited the fastest rate of color change (i.e., chlorophyll degradation) due to their higher rate of $\mathrm{C}_{2} \mathrm{H}_{4}$ biosynthesis and susceptibility to $\mathrm{C}_{2} \mathrm{H}_{4}$ action (Purvis and Barmore, 1981).

Ethylene biosynthesis rate. Air-treated fruit had a significant and sustained increase in $\mathrm{C}_{2} \mathrm{H}_{4}$ biosynthesis compared to all other treatments (Fig. 1). The $2 \% \mathrm{O}_{2}+5 \% \mathrm{CO}_{2}$ treatment consistently had the lowest $\mathrm{C}_{2} \mathrm{H}_{4}$ biosynthesis rate, while the air $+5 \% \mathrm{CO}_{2}$ and the $2 \% \mathrm{O}_{2}$ treatments were intermediate. There was a significant difference in $\mathrm{C}_{2} \mathrm{H}_{4}$ biosynthesis among all treatments in months 2 through 4, and the combination of low $\mathrm{O}_{2}$ and elevated $\mathrm{CO}_{2}$ had a synergistic effect in suppressing $\mathrm{C}_{2} \mathrm{H}_{4}$ biosynthesis.

In vitro ACS activity. In vitro ACS activity (Fig. 2) was highly correlated to in vivo $\mathrm{C}_{2} \mathrm{H}_{4}$ biosynthesis rates. Air treated fruit had a significant and sustained increase in ACS activity. Induction of ACS activity was greatly suppressed in the $2 \% \mathrm{O}_{2}+5 \% \mathrm{CO}_{2}$ treatment and ACS activity in this treatment did not significantly increase during the experiment. The air $+5 \% \mathrm{CO}_{2}$ and the $2 \% \mathrm{O}_{2}$ treatments were intermediate in ACS activity compared to the air and $2 \% \mathrm{O}_{2}+5 \% \mathrm{CO}_{2}$ treatments. Low $\mathrm{O}_{2}$ and and/or elevated levels of $\mathrm{CO}_{2}$ can act individually and synergistically to suppress in vitro ACS activity and suppression of ACS enzyme activity is highly correlated to inhibition of in vivo $\mathrm{C}_{2} \mathrm{H}_{4}$ biosynthesis.

Elevated levels of $\mathrm{CO}_{2}$ (i.e., $6 \%$ and $10 \%$ ) have previously been reported to delay induction and reduce the in vitro activity of ACS in apples (Bufler, 1984). However, the mode of action by which reduced levels of $\mathrm{O}_{2}$ impede $\mathrm{C}_{2} \mathrm{H}_{4}$ biosynthesis has generally been thought to be by impairment of the specific activity of $\mathrm{ACO}$, since $\mathrm{O}_{2}$ is required for the conversion of $\mathrm{ACC}$ to $\mathrm{C}_{2} \mathrm{H}_{4}$ (Abeles et al., 1992). Our data indicate that induction of ACS activity is delayed and reduced by storage in a $2 \% \mathrm{O}_{2}$ atmosphere. The slowed induction of ACS is probably caused by reduced affinity between $\mathrm{C}_{2} \mathrm{H}_{4}$ and its receptor (Burg and Burg, 1967). Low $\mathrm{O}_{2}$ tensions are believed to block the signal transduction pathway involved with response to $\mathrm{C}_{2} \mathrm{H}_{4}$ perception at the receptor site, and hence prevent induction of autocatalytic $\mathrm{C}_{2} \mathrm{H}_{4}$ biosynthesis. Another possibility is that low $\mathrm{O}_{2}$ tensions may be reducing System $\mathrm{IC}_{2} \mathrm{H}_{4}$ biosynthesis and this may be delaying induction of the competency to ripen (i.e., the appearance of the System $\mathrm{IIC}_{2} \mathrm{H}_{4}$ receptor, which is responsible for the upregulation of ACS).

In vitro ACO activity. In vitro $\mathrm{ACO}$ activity significantly increased in all treatments during 4 months of storage (Fig. 3). The air and the air $+5 \% \mathrm{CO}_{2}$ treatments experienced the greatest increase in ACO activity and there was no significant difference between these two treatments. The $2 \% \mathrm{O}_{2}$ and $2 \% \mathrm{O}_{2}+5 \% \mathrm{CO}_{2}$ treatments exhibited suppressed induction of ACO activity compared to the air and air $+5 \% \mathrm{CO}_{2}$ treatments, but accumulation of active ACO protein was not completely inhibited by any of the treatments tested. Ethylene biosynthesis was not as highly correlated to ACO activity as to ACS activity and only a small amount of $\mathrm{C}_{2} \mathrm{H}_{4}$ biosynthesis inhibition can be accounted for by suppressed induction of ACO activity.

Our data and numerous reports in the scientific literature demonstrate that reduced $\mathrm{O}_{2}$ and/or elevated $\mathrm{CO}_{2}$ atmospheres inhibit the conversion of ACC to $\mathrm{C}_{2} \mathrm{H}_{4}$ (Adams and Yang, 1979; Chaves and Tomas, 1984). However, apple tissues' reduced ability to convert ACC to $\mathrm{C}_{2} \mathrm{H}_{4}$, under commercially applied controlled atmosphere regimes, may have only minimal impact on reducing $\mathrm{C}_{2} \mathrm{H}_{4}$ biosynthesis, and extending the storage life of apples.

ACO Western blot. The abundance of the ACO protein during the experiment was determined by Western blot analysis (Fig. 4). The abundance of the ACO protein increased in all treatments over time, with the exception of the air treatment that had a peak in ACO protein after 2 months of storage. The ACO protein was undetectable after 2 months of storage in an atmosphere of $2 \% \mathrm{O}_{2}$ or $2 \% \mathrm{O}_{2}$ $+5 \% \mathrm{CO}_{2}$, while large amounts of the protein were present in the air treated fruit. A small amount of the ACO protein was found in the air $+5 \% \mathrm{CO}_{2}$-treated fruit after 2 months of storage, but it was significantly less than in the air-treated fruit. Between months 2 and 4, air treated fruit began to experience a decline in ACO protein abundance, while all other treatments experienced an increase in ACO protein abundance. After 4 months of storage ACO protein abundance was greater in apples held in $2 \% \mathrm{O}_{2}$, air $+5 \% \mathrm{CO}_{2}$ or $2 \%$ $\mathrm{O}_{2}+5 \% \mathrm{CO}_{2}$ treatments than in air-treated fruit. Interestingly, after

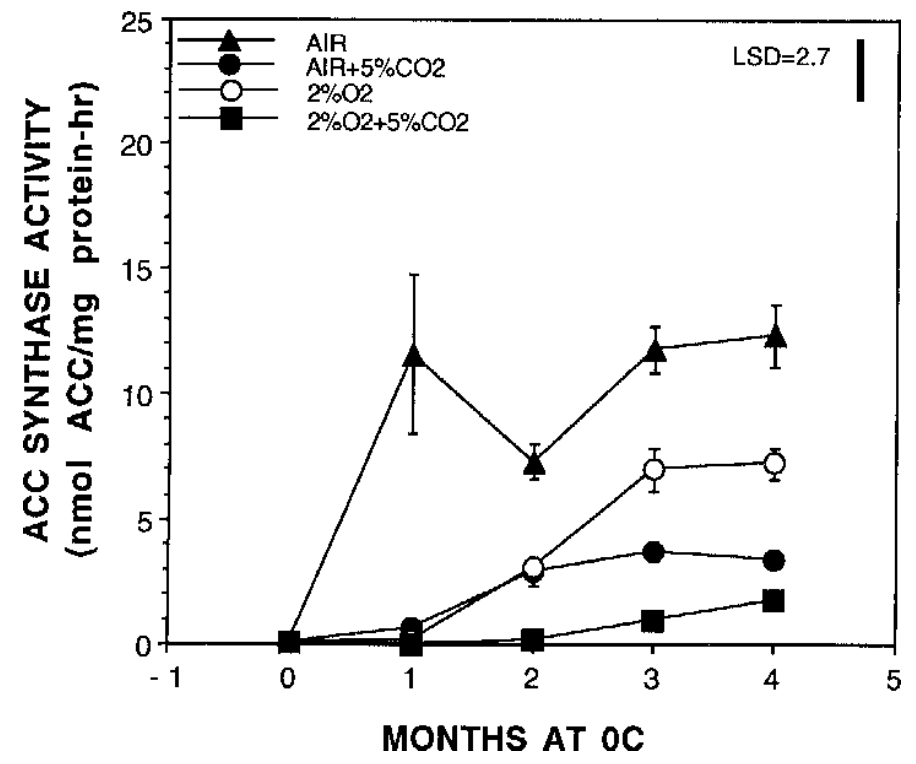

Fig. 3. In vitro ACO activity of 'Golden Delicious' apples held in atmospheres of air, air $+5 \% \mathrm{CO}_{2}, 2 \% \mathrm{O}_{2}$, or $2 \% \mathrm{O}_{2}+5 \% \mathrm{CO}_{2}$ at $0{ }^{\circ} \mathrm{C}$. Data are the means $( \pm \mathrm{SE})$ of three replicates. Pooled LSD at the $5 \%$ level is shown. 


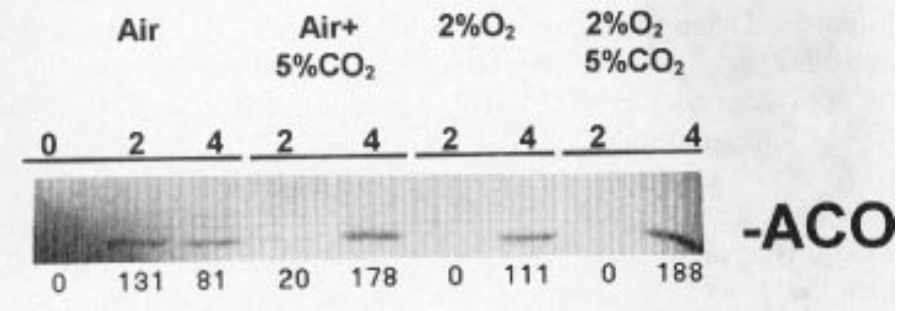

Fig. 4. Western blot analysis of ACO from 'Golden Delicious' apples held in atmospheres of air, air $+5 \% \mathrm{CO}_{2}, 2 \% \mathrm{O}_{2}+98 \% \mathrm{~N}_{2}$, or $2 \% \mathrm{O}_{2}+5 \% \mathrm{CO}_{2}$ at $0{ }^{\circ} \mathrm{C}$ for 0,2 , or 4 months. Proteins $(30 \mu \mathrm{g} / \mathrm{lane})$ were separated by SDS-PAGE, transferred to a nylon membrane and reacted with the antibody. Individual bands were quantified using an Alpha Innotech (IS-1000) digital imaging system (San Leandro, Calif.) and are represented by the number printed below each ACO band. The ACO bands have an approximate molecular mass of $39 \mathrm{kd}$ as determined by biotinylated molecular weight markers.

4 months of storage in vitro ACO activity in apples kept in $2 \% \mathrm{O}_{2}$ or $2 \% \mathrm{O}_{2}+5 \% \mathrm{CO}_{2}$ was significantly less than in the air control apples. This indicates that there was an accumulation of inactive ACO in the $2 \% \mathrm{O}_{2}$ and $2 \% \mathrm{O}_{2}+5 \% \mathrm{CO}_{2}$ treatments. This may be due to treatment effects on the degradation rate of inactive proteins or slowed post-translational modification of the ACO protein. It is currently not known whether or not the ACO protein requires posttranslational modification for activation, but Dilley (1995, personal communication) has reported that post-translational phosphorylation may be necessary for activation of the ACO protein. Atmospheres reduced in $\mathrm{O}_{2}$ and/or elevated in $\mathrm{CO}_{2}$ have been shown to effect the respiration rate and the ATP pools of various plant tissues (Siriphanich, 1984; Hess et al., 1993). Reduced ATP pools due to storage in low $\mathrm{O}_{2}$ and/or elevated $\mathrm{CO}_{2}$ atmospheres may effect the phosphorylation potential of the treated tissues, and in turn, reduce catalytic ability of proteins such as ACO.

ACS Northern blot analysis. The abundance of ACS mRNA transcripts present was determined by Northern blot analysis (Fig. 5). At harvest, there were no detectable ACS transcripts present and all treatments showed a significant increase in ACS transcript abundance over time. Air treated fruit reached a maximum abundance of ACS mRNA transcripts by the second month of storage. After 2 months of storage, treatments of $2 \% \mathrm{O}_{2}$ and air $+5 \% \mathrm{CO}_{2}$ had a significantly lower abundance of ACS transcripts as compared to the air treatment, while the $2 \% \mathrm{O}_{2}+5 \% \mathrm{CO}_{2}$ treatment had no detectable ACS mRNA. Between months 2 and 4, ACS transcript abundance increased significantly in the $2 \% \mathrm{O}_{2}$, air $+5 \%$ $\mathrm{CO}_{2}$ and $2 \% \mathrm{O}_{2}+5 \% \mathrm{CO}_{2}$ treatments, but never attained the levels that were present after 2 months in air storage. Apples treated with reduced $\mathrm{O}_{2}$ and/or elevated $\mathrm{CO}_{2}$ atmospheres had a significantly

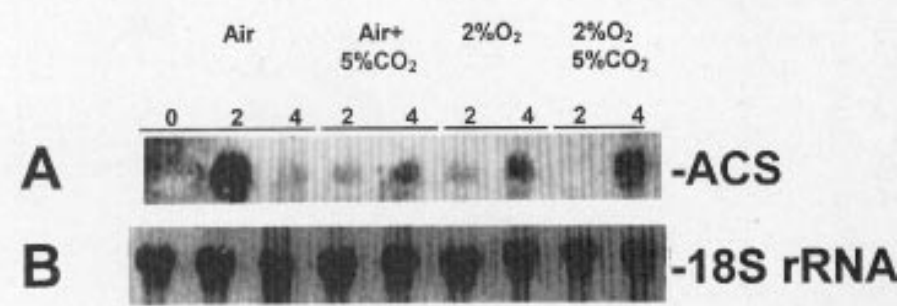

Fig. 5. Northern blot analysis of ACS mRNAs in 'Golden Delicious' apples held in atmospheres of air, air $+5 \% \mathrm{CO}_{2}, 2 \% \mathrm{O}_{2}+98 \% \mathrm{~N}_{2}$, or $2 \% \mathrm{O}_{2}+5 \% \mathrm{CO}_{2}$ at $0{ }^{\circ} \mathrm{C}$ for 0,2 , or 4 months. Total RNA ( $25 \mu \mathrm{g} /$ lane) was separated by formaldehyde agarose gel electrophoresis and blots were (A) analyzed for hybridization to the [32P]dCTP-labeled pAAS2 ACS probe and (B) stained with methylene blue to visualize the $18 \mathrm{~S}$ rRNA as an internal control. The ACS bands had an approximate molecular mass of $1.9 \mathrm{~kb}$ as determined by RNA molecular weight markers. reduced abundance of ACS transcripts as compared to air-treated fruit. ACS transcript abundance was very low in all treatments and autoradiography was carried out for $14 \mathrm{~d}$ to visualize the transcripts seen in Fig. 5. The ability of the fruit tissue to convert AdoMet to ACC is very tightly regulated by a low transcript abundance and rapid protein turnover rate (Kim and Yang, 1992). Therefore, the significant reductions in ACS transcript abundance due to storage in atmospheres reduced in $\mathrm{O}_{2}$ and/or enriched in $\mathrm{CO}_{2}$, have a large impact on the amount of ACS protein and the net biosynthesis rate of $\mathrm{C}_{2} \mathrm{H}_{4}$

The reduction in ACS transcript abundance in air treated fruit between months 2 and 4 may be due to a decline in the transcription rate of the ACS gene, or it may be an artifact, caused by degradation of mRNA transcripts during extraction. Total inhibition of ribonuclease activity during extraction of mRNA from apples in the latter stages of ripening is almost impossible to achieve (Cregoe et al., 1993). Figure 5 shows evidence that the total RNA extracted and utilized to represent 4-month air-stored apples may have undergone some ribonuclease degradation and may not be representative of the true mRNA population present during that time of development and senescence. However, all lanes have intact and undegraded $18 \mathrm{~S}$ ribosomal bands.

ACO Northern blot analysis. The abundance of ACO transcripts present was determined by Northern blot analysis (Fig. 6). At harvest, there were no detectable ACO transcripts present and all treatments showed a significant increase in ACO transcript abundance over time. Induction and suppression of ACO mRNA followed the same general pattern as that seen for ACS, except that ACO transcripts were detectable after 2 months of storage in all treatments. Although ACO mRNAs were readily abundant in the air $+5 \% \mathrm{CO}_{2}, 2 \% \mathrm{O}_{2}$ and $2 \% \mathrm{O}_{2}+5 \% \mathrm{CO}_{2}$ treatments after 2 months, ACO western blot analysis demonstrated that ACO protein abundance was very low in the air $+5 \% \mathrm{CO}_{2}$ treatment and below the level of detection in the $2 \% \mathrm{O}_{2}$ and $2 \% \mathrm{O}_{2}+5 \% \mathrm{CO}_{2}$ treatments. These data indicate that the three CA treatments may be post-transcriptionally limiting translation of ACO mRNA to protein. However, ACO mRNA abundance was at least an order of magnitude greater than that of ACS and autoradiography was carried out for only $4 \mathrm{~h}$ to visualize the transcripts as seen in Fig. 6 . Therefore, even though reduced $\mathrm{O}_{2}$ and/or enriched $\mathrm{CO}_{2}$ atmospheres significantly suppressed induction ACO transcripts (i.e., in time and quantity) this suppression had little impact on the $\mathrm{C}_{2} \mathrm{H}_{4}$ biosynthesis rate. ACO mRNA transcripts are very abundant in the ripening apples and reduction in their abundance due to treatment with atmospheres reduced in $\mathrm{O}_{2}$ and/or enriched in $\mathrm{CO}_{2}$, is not great enough to make the conversion of $\mathrm{ACC}$ to $\mathrm{C}_{2} \mathrm{H}_{4}$ the in vivo rate limiting step in $\mathrm{C}_{2} \mathrm{H}_{4}$ biosynthesis. However, atmospheres reduced in $\mathrm{O}_{2}$ and/or enriched in $\mathrm{CO}_{2}$ may be affecting the post-transcriptional and post-translational processing of ACO. Thereby, reducing the abundance of active ACO protein and causing inhibition of $\mathrm{C}_{2} \mathrm{H}_{4}$ biosynthesis.

In this study we have provided evidence as to the mechanisms by which reduced $\mathrm{O}_{2}$ and/or elevated levels of $\mathrm{CO}_{2}$ inhibit the biosynthesis of $\mathrm{C}_{2} \mathrm{H}_{4}$ in apples. Reduced $\mathrm{O}_{2}$ and/or elevated levels of $\mathrm{CO}_{2}$ atmospheres impede $\mathrm{C}_{2} \mathrm{H}_{4}$ biosynthesis directly by reducing ACO catalytic ability to convert ACC to $\mathrm{C}_{2} \mathrm{H}_{4}$ and indirectly by blocking upregulation of the genes encoding ACS and ACO. However, reduced $\mathrm{O}_{2}$ and/or elevated $\mathrm{CO}_{2}$ atmospheres primarily act to reduce $\mathrm{C}_{2} \mathrm{H}_{4}$ biosynthesis by delaying and suppressing expression of ACS at the transcriptional level and by reducing the abundance of active ACO protein. The theory that reduced $\mathrm{O}_{2}$ and/ or elevated $\mathrm{CO}_{2}$ atmospheres impede the signal transduction pathway involved in upregulation of $\mathrm{C}_{2} \mathrm{H}_{4}$ biosynthesis was first 


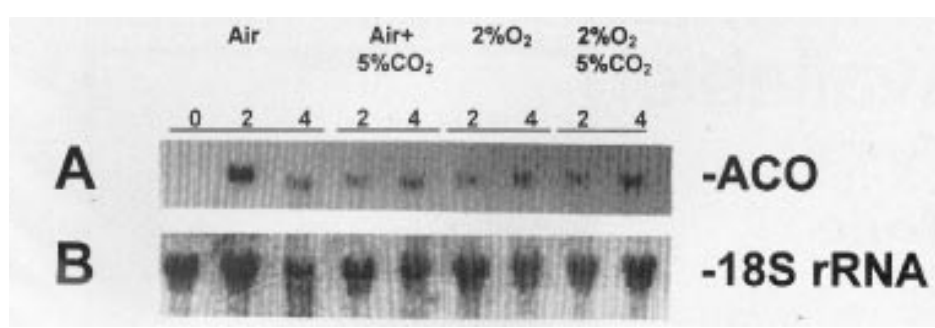

Fig. 6. Northern blot analysis of ACO mRNAs in 'Golden Delicious' apples held in atmospheres of air, air $+5 \% \mathrm{CO}_{2}, 2 \% \mathrm{O}_{2}+98 \% \mathrm{~N}_{2}$, or $2 \% \mathrm{O}_{2}+5 \% \mathrm{CO}_{2}$ at $0^{\circ} \mathrm{C}$ for 0,2 , or 4 months. Total RNA ( $25 \mu \mathrm{g} /$ lane) was separated by formaldehyde agarose gel electrophoresis and blots were (A) analyzed for hybridization to the [32P]dCTP-labeled pAE12 ACO probe and (B) stained with methylene blue to visualize the $18 \mathrm{~S}$ rRNA as an internal control. The ACO bands had an approximate molecular mass of $1.3 \mathrm{~kb}$ as determined by RNA molecular weight markers.

proposed by Burg and Burg in 1967. Via the use of modern molecular biological techniques we have provided evidence to support this hypothesis, by demonstrating that translational upregulation of ACS is inhibited by atmospheres elevated in $\mathrm{CO}_{2}$ and/or reduced in $\mathrm{O}_{2}$.

\section{Literature Cited}

Abeles, F.B., P.W. Morgan, and M.E. Saltveit. 1992. Ethylene in plant biology. 2nd ed. Academic Press, New York.

Adams, D.O. and S.F. Yang. 1979. Ethylene biosynthesis: Identification of 1-aminocyclopropane-1-carboxcylic acid as an intermediate in the conversion of methionine to ethylene. Proc. Natl. Acad. Sci. USA 76:170-174.

Banks, N.H., S. Elyatem, and T. Hammat. 1984. The oxygen affinity of ethylene production by slices of apple fruit tissue. Acta Hort. 157:257260

Birkett, C.R., K.E. Foster, L. Johnson, and K. Gull. 1985. Use of monoclonal antibodies to analyze expression of a multi-tubulin family. FEBS Lett 187:211-218.

Bradford, M.M. 1976. A rapid and sensitive method for the quantification of microgram quantities of protein-dye binding. Anal. Biochem. 72:248254.

Bufler, G. 1984. Ethylene-enhanced 1-aminocyclopropane-1-carboxcylate acid synthase activity in ripening apples. Plant Physiol. 75:192-195.

Burg, S.P. and E.A. Burg. 1967. Molecular requirements for the biological activity of ethylene. Plant Physiol. 42:144-152.

Burg, S.P. and K.V. Thimann. 1959. The physiology of ethylene formation in apples. Proc. Natl. Acad. Sci. USA 45:355-344.

Chaves, A.R. and J.O. Tomas. 1984. Effect of a brief $\mathrm{CO}_{2}$ exposure on ethylene production. Plant Physiol. 76:88-91.

Cregoe, B.A., G.S. Ross, and C.B. Watkins. 1993. Changes in protein and mRNA expression during cold storage of 'Cox's Orange Pippin' apple fruit. Acta Hort. 326:315-323.
Dong, J.G., J.C. Fernandez-Maculet, and S.F. Yang. 1992. Purification and characterization of 1-aminocylcopropane-1-carboxylate oxidase from apple fruit. Proc. Natl. Acad. Sci. USA 89:9789-9793.

Dong, J.G., W.T. Kim, W.K. Yip, G.A. Thompson, L. Li, A.B. Bennett, and S.F. Yang. 1991. Cloning of a cDNA encoding 1-aminocyclopropane1-carboxylate synthase and expression of its mRNA in ripening apple fruit. Planta 185:38-45.

Fernandez-Maculet, J.C. and S.F. Yang. 1992. Extraction and partial purification of the ethylene-forming enzyme from apple fruit. Plant Physiol. 99:751-754.

Herrin, D.L. and G.W. Schmidt. 1988. Rapid, reversible staining of Northern blots prior to hybridization. BioTechniques 3:196-200.

Hess, B., D. Ke, and A.A. Kader. 1993. Changes in intracellular pH, ATP, and glycolytic enzymes in 'Hass' avocado in response to low $\mathrm{O}_{2}$ and high $\mathrm{CO}_{2}$ stresses. Proceedings 6th Intl. Controlled Atmosphere Research Conf., Cornell Univ., Ithaca, N.Y. p. 1-9.

Kim, W.T. and S.F. Yang. 1992. Turnover of 1-aminocyclopropane-1carboxcylic acid synthase protein in wounded tomato fruit tissue. Plant Physiol. 100:1126-1131.

Kollas, D.A. 1964. Preliminary investigation of the influence of controlled atmosphere storage on organic acids in apples. Nature 204:758.

Laemmli, U.K. 1970. Cleavage of structural proteins during the assembly of the head of bacteriophage T4. Nature 227:680-685.

Manning, K. 1991. Isolation of nucleic acids from plants by differential solvent precipitation. Anal. Biochem. 195:45-50.

McMurchie, E.J., W.B. McGlasson, and I.L. Eaks. 1972. Treatment of fruit with propylene gives information about the biogenesis of ethylene. Nature 237:235-236.

Paull, R. and N.J. Chen. 1990. Heat shock response in field grown papaya. J. Amer. Soc. Hort. Sci. 115:623-631.

Peacock, B.C. 1972. The role of ethylene in the initiation of fruit ripening. Q. J. Agr. Animal Sci. 29:137-145.

Poneleit, L.S. and D.R. Dilley. 1993. Carbon dioxide activation of 1aminocyclopropane-1-carboxylate (ACC) oxidase in ethylene biosynthesis. Postharvest Biol. Technol. 3:191-199.

Purvis, A.C. and C.R. Barmore. 1981 Involvement of ethylene in chlorophyll degradation in the peel of citrus fruit. Plant Physiol. 68:854-856.

Sambrook, J., E.F. Fritsch, and T. Maniatis. 1989. Molecular cloning: A laboratory manual. Cold Springs Harbor Press, Cold Springs Harbor, N.Y.

Siriphanich, J. 1984. Carbon dioxide effects on phenolic metabolism and intracellular $\mathrm{pH}$ of crisphead lettuce (Lactuca sativa $\mathrm{L}$.). PhD diss. Univ. of California, Davis.

Smith, J.J. and P. John. 1993. Activation of 1-aminocylcopropane-1carboxylate oxidase by bicarbonate/carbon dioxide. Phytochemistry 32:1381-1386.

Yip, W.K., J.G. Dong, and S.F. Yang. 1991. Purification and characterization of 1-aminocyclopropane-1-carboxylate synthase from apple fruit. Plant Physiol. 95:251-257.

Yip, W.K., X.Z. Jiao, and S.F. Yang. 1988. Dependence of in vivo ethylene production rate on 1-aminocyclopropane-1-carboxcylic acid content and oxygen concentrations. Plant Physiol. 88:553-558. 